\title{
ESTABILIZAÇÃO DE SOLO COM ADIÇÃO DE LODO DE PAPEL CALCINADO APLICADO À PAVIMENTAÇÃO
}

\author{
L. Furlan ${ }^{1}$; M. Prates ${ }^{2}$; E. Damin ${ }^{3}$ \\ 1,2 Acadêmicas do curso de Engenharia Civil, UDC, Foz do Iguaçu/PR \\ ${ }^{3}$ Engenheiro Civil, especialista, docente do Curso de Engenharia Civil, UDC, Foz do Iguaçu/PR \\ larissa.furlan@hotmail.com¹,makelyps@hotmail.com², eduardodamin@hotmail.com ${ }^{3}$
}

Resumo: Diante da precariedade das rodovias e ruas em todo o país, a utilizaçáo do solo como base e sub-base de pavimentos tem sido uma solução economicamente e ambientalmente viável para pavimentos de baixo custo. Porém nem sempre o solo atende às exigências necessárias para sua utilização. Nesse sentido, um resíduo que apresenta características favoráveis para ser estudado na estabilização e reforço de solos é o proveniente das estaçóes de tratamento de efluentes das indústrias de papel e celulose, conhecido como lodo de papel, que surpreende pelo grande volume produzido. Assim sendo, o objetivo dessa pesquisa é avaliar o comportamento mecânico do compósito solo-lodo de papel através de ensaios laboratoriais. Espera-se com os resultados que o resíduo possa servir como aditivo estabilizante para aplicação em base e sub-base de pavimentos, para uso em substituição total ou parcial de materiais tradicionais já utilizados para esse fim, como a cal, o cimento, entre outros.

Palavras-chave: Lodo de papel, Estabilização de solo, Pavimento econômico.

\section{Introduçáo}

Com a crescente necessidade de reutilização de resíduos industriais, com o objetivo de reduzir os impactos ambientais, os materiais pozolânicos que seriam descartados pelas indústrias tornam-se uma grande motivação para esta pesquisa, buscando a redução de custo e o desenvolvimento sustentável. Nesse contexto, de acordo com [2], um resíduo que apresenta pozolanicidade após calcinação a $600^{\circ} \mathrm{C}$, que é interessante a ser estudado como aditivo estabilizador é o lodo de papel, proveniente das Estaçóes de Tratamento de Efluentes (ETE) das indústrias de papel e celulose, que surpreende pela quantidade que é gerado. Segundo [1], apesar de sofrerem variações de acordo com o processo produtivo, matérias-primas e insumos utilizados por cada indústria, são fontes importantes de impurezas minerais e compostos inorgânicos, por isso, são reconhecidos mundialmente pela sua potencialidade de serem utilizados na construção civil. Assim sendo, com esse trabalho pretende-se avaliar através de ensaios de laboratório se a incorporação do lodo de papel calcinado irá trazer melhorias na estabilização de solo e no seu comportamento mecânico para aplicação como aditivo estabilizador em base e sub-base de pavimentos. 


\section{Metodologia}

O trabalho pretende analisar o comportamento mecânico do Latossolo Vermelho Distroférrico com a incorporação do lodo de papel calcinado, através do ensaio de compactação, série de floculação, ensaio de compressão simples, ensaio de pH e CBR (Índice de Suporte Califórnia).

\section{Resultados esperados/Conclusóes}

Espera-se que o lodo de papel possa vir a substituir total ou parcialmente materiais tradicionais utilizados na estabilização de solo tal qual a cal e o cimento.

\section{Referências}

[1] FOELKEL, C. Resíduos Sólidos Industriais do Processo de Fabricação de Celulose e Papel de Eucalipto, Parte 03: Lodos \& Lodos. Eucalyptus Online Book. 2010.

[2] SOARES, J. Avaliaçáo da atividade pozolânica do lodo de papel proveniente de indústria de papel reciclado do centro-oeste do Paraná. Foz do Iguaçu. Centro Universitário Dinâmica das Cataratas. 2013. 